\title{
Elvira Stefanović,
}

Stručni saradnik-pedagog,

OŠ „Petefi Šandor“ Novi Sad

Pedagoško društvo Vojvodine

DOI 10.19090/ps.2020.2.208-214

\section{PRIKAZ KONFERENCIJE, ,SUSRET GODINA UZLETA I ŠKOLE - BUDI DEO REŠENJA" Stručni skup u organizaciji Pedagoškog društva Vojvodine}

Konferencija Susret „Godina uzleta“ i škole - Budi deo rešenja!“ održana je u Novom Sadu 08.10.2020. godine u Novom Sadu. Akreditovao ju je Pedagoški zavod Vojvodine (broj rešenja: 510/1, 20.07.2020), kao oblik stručnog usavršavanja, konferencija, u organizaciji Pedagoškog društva Vojvodine.

Nove Osnove programa predškolskog vaspitanja i obrazovanja „Godine uzleta“ se školske 2019. godine sukcesivno uvode u preškolske ustanove u Srbiji. Osnovni postulati koje koncepcija afirmiše su: vera u kapacitete dece predškolskog uzrasta da aktivno učestvuju u svom učenju i razvoju, značaj igre na ovom uzrastu i značaj zajedničkog učešća dece i odraslih za učenje i razvoj; profesija vaspitača kao jedinstvena profesija u odnosu na druge, etička i refleksivna po svojoj suštini, koja se zasniva na složenim i osobenim komepetencijama; jedinstvena profesionalna uloga saradnika u razvijanju refleksivne prakse i kvalitetnog realnog programa kroz promenu kulture i strukture vrtića; povezivanje sa lokalnom zajednicom i porodicom i značaj njihove uloge u praksi predškolskog vaspitanja i obrazovanja («Godine uzleta», 2018).

Cilj konferencije „SUSRET „Godina uzleta“ i škole - Budi deo rešenja” je bio odgovoriti na pitanje u kojoj meri je koncepcija novih osnova programa predškolskog vaspitanja i obrazovanja kompatibilna sa učenjem orijentisanim na ishode kojima teži takođe reformisano osnovno obrazovanje i koliko je proces tranzicije iz predškolske ustanove u školu podržavajući za dete u ovim novim okvirima.

Konfrencija je imala dva dela - plenarni deo i rad u vidu diskusionih foruma. Plenarni deo je održan u dva modaliteta - u neposrednoj komunikaciji izlagača i učesnika, ali i u on-line formi koji su učesnici mogli pratiti uživo preko Zoom platforme. Diskusioni forumi bili su organizovani u on-line formi preko Moodle platforme kojoj su učesnici pristupali nakon završenog plenarnog dela.

Konferenciju je otvorila predsednica Pedagoškog društva Vojvodine, Sanja Rista Popić, koja je kratko predstavila Društvo i aktivnosti Društva.

Bojana Perić Prkosovački je kratko predstavila časopis "Pedagoška stvarnost", upoznala je učesnike sa dugom tradicijom, te pročitala odlomak koji je oslikavao si- 
tuaciju u pedagogiji sredinom prošlog veka, ali čiji se zaključci mogu primeniti i na sadašnji trenutak.

Na konferenciji su govorili:

- Dr Otilia Velišek-Braško, pedagog, profesor VŠSSOV Novi Sad, trener za „Godine uzleta“ na temu Teorijski aspekti novih osnova - Šta nam donose i zašto Godine uzleta

- Aleksandra Marcikić, vaspitač specijalista PU „Mladost“ Bačka Palanka, trener za „Godine uzleta“ koja je zbog nemogućnosti dolaska poslala snimak svog predavanja uz prezentaciju na temu Primene Godine uzleta u kontekstu pripreme za školu - šira slika

- Sanja Đaković, PU „Radosno detinjstvo“ Novi Sad, na temu Priprema za školu kroz projektni pristup (primeri dobre prakse)

- Sonja Paripović, nastavnik razredne nastave OŠ "Sonja Marinković" Novi Sad, na temu Kako se učitelj sprema za prvake? Kako se radi u prvom razredu?

- Elvira Stefanović, pedagog OŠ „Petefi Šandor“ Novi Sad, na temu Uloga stručnog saradnika prilikom prelaska dece u školu u kontekstu reformi

- Dragana Đurić, psiholog, v.d. direktor Nacionalne asocijacije roditelja i nastavnika Srbije, na temu Rezultati istraživanja o polasku dece u školu u kontekstu reforme (ugao porodice, vrtića i škole).

Drugi deo konfrencije koji se odvijao on-line na Moodle platformi bio je organizovan u formi foruma na tri teme koji su učesnici mogli pristupiti u periodu od sedam dana. Teme o kojima se promišljalo i diskutovalo na forumima su bile: Šta treba drugačije raditi u ovoj reformi za doček prvaka?; Ko i kako treba da se sprema za polazak dece u školu?; i Predlog plana prelaska dece u školu - Konkretni koraci u prelazu dece u školu (Ko? Kad? Gde? Šta?).

Teme za diskusiju pratio je moderatorski tim skupa: Doc. dr Stanislava Marić Jurišin, UNS Filozofski fakultet Odsek za pedagogije; dr Borka Malčić, asistent UNS Filozofski fakultet Odsek pedagogija; Elvira Stefanović, pedagog u OŠ „Petefi Šandor, Novi Sad; Prof. dr Otilia Velišek-Braško, VŠSSOV Novi Sad, za sekciju na mađarskom jeziku i Marina Jurik, psiholog u SSŠ, za sekciju na slovačkom jeziku.

\section{Zaključci}

Zaključci do kojih se došlo nakon plenarnih izlaganja se poklapaju sa zaključcima na forumima i mogli bi se objediniti:

\section{Zakonska regulativa}

Postoji potreba da se pravilnikom uredi put saradnje vrtića i škole u celoj godini pred polazak u prvi razred, a vođenje dokumentacije uskladi i standardizuje. Škola i vrtić u svom delovanju sa deteteom i u odnosu na dete moraju imati aktivnosti koje se prožimaju. 


\section{Kompetencije profesionalaca}

Postoje akreditovani seminari na temu predškolskog vaspitanja i obrazovanja ali vaspitačima je potrebno još obuka u vezi sa novim Osnovama programa. Mora se krenuti od samog starta i promeniti inicijalno obrazovanje praktičara i stručno usavršavanje profesionalaca.

\section{Povezanost profesionalca}

Učitelji nemaju dovoljno znanja u vezi sa načinom kako vaspitači rade i trebalo bi da se upoznaju kako bi prilagodili svoj rad. Potrebno je da se uspostavi kontinuirana saradnja na više polja rada. U prvom redu je upoznavanje učitelja sa primerima dobre prakse rada u predškolskoj ustanovi. Tako bi učitelji stekli prve informacije o o novom program rada. Dalje, inicijalno obrazovanje vaspitača i učitelja inovirati u pravcu menjanja obrazovne paradigme, shvatanja deteta na humanističkim i holističkim principima kao i učenika u osnovnoj školi. Ovo proizilazi iz potrebe da se promene uvode paralelno u svim elementima obrazovnog sistema. Pored toga što bi "Godine uzleta" trebalo približiti školi, zaključak je da se neminovno nameće činjenica približavanja školskog programa/programa nastave i učenja "Godini uzleta". Odnosno, nova tumačenja reformnih programa i njihova primena je neophodna kako bi se obezbedio logičan sled u reformama ova dva nivoa obrazovanja. Dok se to ne desi, samo su učitelji i vaspitači ti koji bi zajedno trebali da rade na usklađivanju i približavanju načina rada i zahteva koje i jedni i drugi postavljaju pred decu u kratkom vremenskom razmaku. Zaključak koji se tokom konferencije više puta nametnuo (i ponovo da ističemo) je da je neophodna kontinuirana saradnja vrtića i škole. Konkretno, vaspitači, učitelji i stručni saradnici obe ustanove na početku školske godine bi trebalo ustanoviti plan tranzicije i raspored radionica koje bi mogle da budu usklađene sa temom projekta koji se realizuje u vrtiću, a ne nužno da prati samo temu škole, odnosno dočeka prvaka. Da bi učionice postale mesto zajedničkog življenja gde nema moć NAD decom, nego moći SA decom, onda i vaspitači i učitelji moraju tako biti tretirani (jedan segment saradnje). Jedan od predloga je bio da se formira zatvorena grupa vaspitača, učitelja i stručnih sardnika na društvenim mrežama gde bi se razmenjivala iskustva, ideje, slike i predstavljale mogućnosti usklađivanja "Godina uzleta" i jedne takve sredine sa tradicionalnom školom, koja je na početku svojih reformi, ali ipak u mogućnosti da dosta stvari prilagodi i promeni.

\section{Fizičko okruženje dece}

Jedan od zaključaka, koji je dobio veliku pažnju učesnika konferencije je fizičko okruženje dece u vrtiću u odnosu na fizičko okruženje dece u školi. Okruženje radne sobe u vrtiću, koja je organizovana i opremljena u skladu sa novom koncepci- 
jom predškolskog vaspitanja i obrazovanja, je opuštenije, podsticajnije, interesantnije, slobodnije, u odnosu na učionicu u školi. Vrtić odiše toplinom, prijatnom atmosferom, poziva na istraživanje i igru, tu deca slobodno mogu da uče i imaju kontakt sa prirodnim materijalima. Ponuđeno im je mnoštvo materijala, dok je tradicionalna učionica hladna, rigidna, strogo uređena, nije podsticajna i upućuje na "red, rad i disciplinu". To je veliki put koji deca moraju da pređu. Kako bi se atmosfera iz vrtića prenela i na škole, nije potrebno mnogo. Ukoliko se i škole malo ne promene, ako se učionice ne pretvore u okruženje koje neće biti na prvi pogled zastrašujuće, proces tranzicije će biti težak. Projektna nastava koja je uvedena u školski plan i program bi trebalo da im u tome pomogne. Školske učionice se u inostranstvu već uveliko menjaju, mislim da je do nas koji radimo u školama da pokrenemo te promene. Učitelji se zaista trude da pomognu deci da prelazak bude što lakši, ali nije sve na njima. Potrebno je uvesti izvesnu reformu u organizaciji prostora i u samim školama, približiti je prethodnom iskustvu deteta, jer samo integrisanim pristupom možemo doći do velikih rezultata kada su u pitanju deca, jer ulaganjem u njih, mi zapravo ulažemo u našu budućnost. A organizacija prostora ne treba da govori - sedi, slušaj, pamti, već dođi, druži se, zabavi se i nauči nešto novo! S obzirom da je znatno izmenjen izgled soba u vrtićima, bilo bi dobro da se razmotri i promena fizičke sredine i prostora u školama. Učionice treba oplemeniti. Na taj način bi sam prelazak iz vrtića u školu bio lakši, deca bi se osećala sigurnije. Pogotovo bi ovo trebalo primeniti prvih mesec ili dva u prvom razredu. Prostornu organizaciju, raspored sedenja, usmerenost i dostupnost kako drugara tako $\mathrm{i}$ učitelja u svakom momentu.

\section{Akteri tranzicije}

Lokalna zajednica: mesne zajednice treba da budu aktivni participatori u procesu tranzicije između vrtića i škole, otvarajući se prema ovim institucijama. Lokalna zajednica može biti partner u realizaciji projektnih aktivnosti putem organizacije mini sajmova posredstvom kojih bi deca imala priliku da bliže upoznaju okruženje predškolske ustanove i škole. Prilikom saradnje sa lokalnom zajednicom dobrobit deteta se ogleda već u samom izlasku iz ustanove $\mathrm{i}$ iskorakom u nepoznato i novo (posete muzejima, pijaci, školi, biblioteci, Domu kulture, vojsci, policiji, domu zdravlja...). Ona može biti mesto i prostor za sticanje integrisanog, funkcionalnog, doživljenog znanja. Saradnjom se postiže celovit proces usvajanja i osvajanja znanja i prilika da dete učestvuje svim svojim bićem u tom procesu. Takođe, lokalna zajednica mogla bi da predstavlja posrednika u okviru bliže saradnje između vrtića i škole i to na dva načina. Najpre bi mogla da se ogleda u uključivanju institucija u lokalnoj zajednici koje bi predstavljale fizički mesto susreta dece koja pohađaju vrtić i dece koja pohađaju školu, pri čemu bi deca, vaspitači i učitelji imali priliku da zajedno kreiraju i realizuju različite aktivnosti. Sa druge strane, bi ta saradnja mogla da se ostvari i posredstvom povezivanja vrtića i škole na lokalnom nivou putem ostvarivanja dijaloga 
o relevantnim temama i pitanjima poput izazova vezanih za usklađivanje načina rada ove dve ustanove (koherentni programi), izazovi sa kojima se susreću, međusobnim očekivanjima... Ovakvi susret bi mogli da budu i medijski propraćeni putem lokalnih medija, namenjenih roditeljima i ostalim akterima vaspitno-obrazovnog procesa. Vrtić bi u svojstvu institucije koja je prva prošla kroz proces promene, mogao da ponudi podršku učiteljima i školi putem prenošenja praktičnih iskustava i zapažanja, odnosno „primerima dobre prakse“. Od pedagoško-psihološke službe: se očekuje intenzivan rad na umrežavanju kolega (pedagoga, psihologa, vaspitača, nastavnika rezredne nastave, stručnih saradnika za muzičko, likovno, fizičko...), zajedničkom planiranju i realizovanju aktivnosti posvećenih deci, roditeljima i zaposlenima i u vrtiću i u školi. Kreiranje i realizovanje radionica od strane pedagoga i psihologa namanjenih roditeljima u procesu tranzicije njihove dece iz jedne institucije u drugu, kao i organizovanje Dana otvorenih vrata u školi. Škola ima zadatak da prati inovativnosti u radu PU, te da pokuša da uskladi svoj rad sa načinom rada u vrtiću i to najpre u nižim razredima osnovne škole, a zatim i u ostalim osiguravajući na taj način stabilniji kontinuitet. Trebalo bi da priprema podsticajnu sredinu za učenje i to pre svega uređenjem i preuređenjem fizičkog prostora, odnosno učionice. Ona osmišljava, organizuje i dočekuje posete predškolaca i njihovih roditelja; podstiče i inicira saradnju sa saradnicima iz predškolskih ustanova i saradnicima iz lokalne zajednice; treba da bude otvorena i spremna za saradnju i promene. U tom procesu treba da bude podsticajna i podržavajuća i za učitelje i za učenika. Učitelj: predstavlja centralnu figuru u saradničkoj mreži (dete, škola, roditelj, vaspitač, lokalna zajednica), a u cilju pružanja podrške deci trebao bi da oplemeni i pripremi učionicu tako da ona predstavlja podsticajnu sredinu za rad dece; da bude upoznat sa načinom rada vaspitača prema novim osnovama programa, kao i sa samom tehnikom projektnog planiranja. Roditelje: treba prihvatiti kao saradnike u procesu tranzicije između vrtića i škole, ali ih isto tako treba edukovati i pripremiti za polazak u školu isto kao i decu i osnažiti da budu podrška svojoj deci. To se može možda najbolje postići uključivanjem putem projekata i u samu pripremu za polazak u školu. Vaspitač priprema dete za život, a samim tim i za školu; on treba kod dece da budi, neguje i podstiče radoznalost. Vaspitače bi trebalo podržati u tome da predstave svoj rad i primere dobre prakse, kako svojim kolegama vaspitačima tako i učiteljima, ali i lokalnoj zajednici. Dete/Deca: treba da uživaju u svim dobrobitima koje im vrtić pruža tokom njihovog odrastanja. Roditelji, vaspitači, učitelji i stručni saradnici bi trebali da pomognu deci da razumeju promene u periodu koji im predstoji, prelaskom iz vrtića u školu, kao i zašto je važno da se ide u školu i šta tamo mogu da očekuju. Potrebno im je ostaviti vremena i prostora za slobodnu i spontanu igru kroz koju razvijaju inicijativu i unutrašnju motivaciju za nekom akcijom i omogućiti da uče „živeći“, a ne pripremati ih za život koji će jednom doći. 


\section{Profesionalna i lična odgovornost}

Najveća odgovornost trebalo bi da pripadne vaspitačima i učiteljima, kao onima koji su realizatori programa i koji će prilagoditi, samostalno kreirati i realizovati plan i program u vrtiću i školi, tako da ne odstupa od zakona, a da bude pristupačan i zanimljiv deci. Ovakav pristup zahteva samoevaluaciju, samorefleksiju, edukaciju, više empatije, tolerancije i fleksibilnosti svih učesnika vaspitno-obrazovonog procesa. Ako želimo da praktičari decu vide kao kompetentne, stvaralački i saradnički orijentisana bića, bića koja su sada i ovde, a ne samo u nastajanju, ali i koja su građani budućnosti, onda moramo krenuti i od samog praktičara i tretirati i njega tako. Važna stvar koja se nameće kao zaključak je da uspešan vaspitač "čuje" decu. On treba da neguje senzitivnost za dečja interesovanja, da uvidi šta je to što inspiriše i pokreće decu, a ne da se oslanja pretežno na uputstva bilo kog plana i programa, jer on treba da bude vodilja, a svaki pojedinačni projekat jedinstveno ostvarenje dece određene grupe i samih vaspitača.

\section{Pedagoške implikacije - moguće aktivnosti}

Više učesnika skupa istaklo je da je moguća harmonizacija reformisanih programa osnova obrazovanja i vaspitanja i "Godine uzleta". Odnosno, novi planovi nastave i učenje u školi, kao i (moguća) projektna nastava su u skladu, mogu da prate elemente programa u PU "Godine uzleta”. Daje se mogućnost da učenici aktivnim savremenim metodama rada, otkrivaju, uče, zaključuju, analiziraju, diskutuju... u podsticajnom, sigurnom okruženju koje mami na učenje, što ukazuje da postoje i mogućnosti i obaveza i u OŠ da se organizuje i opremi podsticajna i izazovna sredina za učenje. Učesnici na onlajn platformi pozvani su da daju svoje predloge aktivnosti u okviru tranzicije. Ideja je bila da se na neki način zajednički napravi ,idealan“ plan tranzicije. Učesnici su davali kratak opis aktivnosti, vreme kada bi se ona realizovala, ko su nosioci aktivnosti i gde bi se aktivnost mogla dogoditi.

Najveći broj aktivnosti je usmeren na decu, ali ima aktivnosti koje su usmerene i na odrasle. To su, pre svega, aktivnosti upućene roditeljima - održavanje informativnih roditeljskih sastanaka, izrada neke vrste informatora, lifleta, škole (osnovne informacije, brojevi telefona...) Dani otvorenih vrata. Aktivnosti koje bi bile usmerene na profesionalce- učitelje pre svega, skoro da nisu navedene. Navedeno je formiranje tima za tranziciju i stručno usavršavanje, upoznavanje učitelja sa radom u PU i vaspitača sa radom u OŠ, boravak učitelja u pripremnoj grupi. Ako želimo da promenimo paradigmu i govorimo o „pripremi škole za decu“, a ne obrnuto, potrebno je osmisliti više aktivnosti u kojima bi, pre svega, budući učitelj imao prilike da dobije relevantne informacije o deci.

Aktivnosti usmerene na decu mogu se posmatrati u odnosu na neki vremenski sled ili po tipu aktivnosti. Po tipu aktivnosti to su, pre svega, one koje se odnose na 
to da budući prvaci odlaze školu i na taj način se upoznaju sa učionicom, rasporedom prostorija, načinom organizovanja rada (predškolski kod prvaka na času) i slično. Predložen je i niz aktivnosti koje bi imale za cilj da se olakša prelazak u školu, ali koje nisu tako očigledne. To su razne sportske, istraživačke, umetničke aktivnosti, razne priredbe, radionice, sadnja drveta, maskenbali, izložba životinja, humanitarni bazari... Učesnici konferencije predlažu i niz aktivnosti koje bi se dešavala na nekom „neutralnom terenu“, koje bi podrazumevala zajedničko učešće dece i iz predškolske ustanove i dece iz škole koje bi takođe imala za cilj da olakšaju ovaj proces. To su različiti vidovi poseta, izleti, ekskurzije, ali i niz aktivnosti u nekoj „neutralnoj zoni“. Na primer zajednička priredba za bake i deke, razne posete pesnika, druženje u biblioteci, muzeju, eksperimenti u prirodi (šuma, bara), oslikavamo trg kredama....

Ako posmatramo vremenski sled može se uočiti da predlažu aktivnosti koje bi bile realizovane tokom cele školske godine. Neke od njih bi se dešavale samo jednom, a neke podrazumevaju kontinuitet.

Možemo zaključiti da profesionalci uviđaju značaj i raznovrsnost aktivnosti koje se mogu realizovati ili se realizuju u okviru tranzicije iz predškolske ustanove u osnovnu školu. Potreban je timski rad i međuinstitucionalno povezivanje, ne samo obrazovnih ustanova, već i uključivanje niza ustanova u okolini- kulturnih, naučnih, socijalnih.... Tranzicija nije posao za jednog čoveka niti posao od jednog dana/nedelje. To je aktivnost koja bi trebala da se realizuje kontinuirano, osmišljeno i isplanirano.

Opšti utisak je da je ovakva razmena ideja poput KONFERENCIJE „SUSRET GODINA UZLETA I ŠKOLE - BUDI DEO REŠENJA" veoma korisna. Učesnici su izrazili svoju veliku potrebu za susretima ovog tipa. Učesnici, mahom iz predškolskih ustanova, ističu nephodnost da se učitelji, nastavnici, saradnici, profesori na visokim školama i fakultetima uključe u ovakav vid edukacije, umrežavanja i saradnje tokom ovog kompleksnog procesa kakav je poces tranzicije dece kroz različite nivoe obrazovanja. 